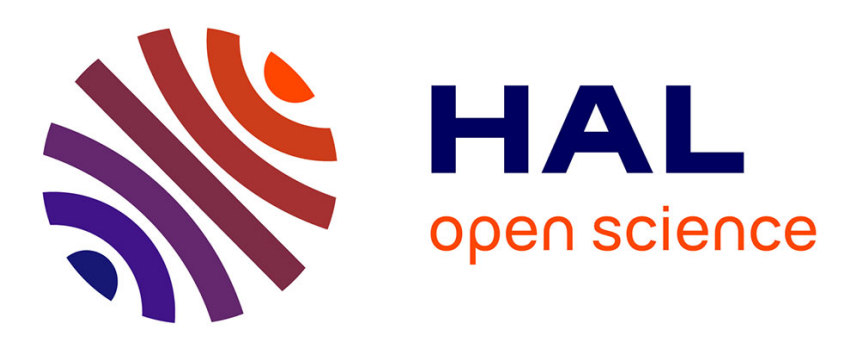

\title{
Organizational socialization tactics: Determining the relative impact of context, content, and social tactics
}

Serge Perrot, Talya N. Bauer, Patrice Roussel

\section{To cite this version:}

Serge Perrot, Talya N. Bauer, Patrice Roussel. Organizational socialization tactics: Determining the relative impact of context, content, and social tactics. Revue de Gestion des Ressources Humaines, 2012, 86, pp.23-37. halshs-00743179

\section{HAL Id: halshs-00743179 \\ https://shs.hal.science/halshs-00743179}

Submitted on 19 Oct 2012

HAL is a multi-disciplinary open access archive for the deposit and dissemination of scientific research documents, whether they are published or not. The documents may come from teaching and research institutions in France or abroad, or from public or private research centers.
L'archive ouverte pluridisciplinaire HAL, est destinée au dépôt et à la diffusion de documents scientifiques de niveau recherche, publiés ou non, émanant des établissements d'enseignement et de recherche français ou étrangers, des laboratoires publics ou privés. 


\title{
Organizational socialization tactics:
}

Determining the relative impact of context, content, and social tactics

\author{
Serge Perrot ${ }^{1}$ \\ Université Paris-Sud \\ serge.perrot@u-psud.fr \\ Faculté Jean Monnet, PESOR Research Center \\ 54 Bd. Desgranges, 92331 Sceaux France \\ Talya N. Bauer \\ Portland State University \\ talyab@sba.pdx.edu \\ PO Box 751 \\ Portland, OR 97207 USA \\ Patrice Roussel \\ Université Toulouse 1 \\ roussel@univ-tlse1.fr \\ CRM , 2, rue du Doyen Gabriel Marty \\ 31042 Toulouse cedex 9 France
}

\begin{abstract}
This article follows a previous research, published in Revue de Gestion des Ressources Humaines, $\mathrm{n}^{\circ} 72$ (2009), examining the relationships between organizational socialization tactics and perceived fit. Using the same database, we made specific hypotheses regarding new and different outcome variables (learning and role innovation), in order to investigate a new research question.
\end{abstract}

The authors would like to thank the three anonymous reviewers for their precious feedback and comments that helped improve the paper.

\footnotetext{
${ }^{1}$ Corresponding author.
} 
Organizational socialization tactics:

Determining the relative impact of context, content, and social tactics

Organizational socialization is known as a process in which employees are transformed through an interactive process between newcomers and their organizations from organizational outsiders to effective insiders (Feldman, 1981). The socialization process is primarily a learning process, although not all learning is considered as organizational socialization (e.g., Haueter, Macan, \& Winter, 2003; Ostroff \& Kozlowski, 1992; Schein, 1968). Specifically, organizational socialization is about learning in three key organizational domains of how things work with the organization, the work group, and the actual job a person is hired to do (Haueter et al., 2003).

Organizational socialization is an important issue for organizations because it contributes to developing the desired newcomers' attitudes and behaviors (Bauer, Bodner, Erdogan, Truxillo, \& Tucker, 2007). In a growing economy, organizations tend to attract, develop, and limit unwanted turnover by developing induction programs with appropriate socialization tactics. During economic downturns, it is also important to make sure that newcomer socialization is effective because recruitment failures can be costly. Estimates of a failed hire range from $25 \%$ to $200 \%$ of the annual compensation for that hire depending on job type (Branham, 2000). Also important is that organizational socialization facilitates the transmission of an organization's culture and provides newcomers with essential clues to make sense of their new work environment (Bauer, Morrison, \& Callister, 1998).

The literature recognizes both the influence of organizations on individuals through the use of socialization tactics (e.g., Van Maanen \& Schein, 1979), and the proactive role of individuals in their own socialization. In this paper, we chose to focus 
on socialization tactics (e.g., Allen, 2006; Jones, 1986; Saks, Uggerslev, \& Fassina, 2007), which characterize the way organizations influence newcomers' socialization processes. Following Van Maanen and Schein (1979), Jones (1986) found that socialization tactics shared a common dimension on a continuum from individualized to institutionalized tactics. Institutionalized tactics are collective, formal, sequential, fixed, serial, and investiture, as opposed to individualized tactics that are individual, informal, random, variable, disjunctive, and divestiture. Previous studies have found that institutionalized tactics (Jones, 1986) were positively related to a large number of outcome variables including job satisfaction and organizational commitment (e.g., Ashforth, Sluss, \& Saks, 2007; Saks et al., 2007; Takeuchi \& Takeuchi, 2009). Six dimensions are used to characterize socialization tactics, that can be grouped into three categories that include context, content, and social tactics (Jones, 1986).

Despite a number of studies exploring the consequences of socialization tactics, an important gap in the literature is determining the relative influence of each type of tactic on socialization outcomes. From a managerial view, organizations can emphasize each of these tactics separately and need to know whether they are differentially related to the desired outcome(s). Because organizations devote a significant amount of resources on newcomers' socialization, it is also important to choose the most effective tactics in determining specific adjustment outcomes (Saks et al., 2007). From a theoretical view, although there is a '...rationale for expecting different tactics to relate differentially to outcomes, researchers have tended not to make differential predictions.' (Bauer et al., 2007: 709). Based on past research one might believe that social tactics are always the most highly correlated with a majority of distal outcomes (Bauer et al., 2007; Saks et al., 2007). However, we contend that this may not be the case when considering specific proximal outcomes, as suggested in one previous study 
using fit perception outcomes (Perrot, 2009). More research is needed that includes proximal outcomes and tests whether patterns of relationships differ across socialization outcomes.

To date, four studies have explored differential effects of tactics with primary data (Cable \& Parsons, 2001; Grant \& Bush, 1996; Jones, 1986; Perrot, 2009). In addition, one study developed related theoretical propositions (Griffin, Colella, \& Goparaju, 2000) and one study meta-analyzed tactics and outcomes (Saks et al., 2007). Although previous empirical studies have contributed to the literature on socialization they used general constructs for outcome variables such as person-organization fit perceptions (e.g. Cable \& Parsons, 2001), organizational value congruence (Grant \& Bush, 1996), or a larger array of indicators of socialization success (Jones, 1986). However, we argue that when the goal of a study is to understand which tactics influence the socialization process proximal outcomes of socialization should be used, as opposed to distal outcomes (e.g., Saks et al., 2007; Wesson \& Gogus, 2005; Wharton, Potter, \& Parry, 2004) that are not specifically related to organizational socialization theory. This study is the first to explore differential predictions of socialization tactics while using proximal learning outcomes of socialization. Furthermore, with the exception of two studies (Grant \& Bush, 1996; Jones, 1986), previous research has typically been based on differences in correlation or regression coefficients to determine which type of socialization tactic was most influential (e.g., Cable \& Parsons, 2001; Saks et al., 2007). As Johnson (2000) notes, the comparison of regression coefficients is not necessarily sufficient to access the relative influence of predictor variables when they are correlated.

Therefore, the present study contributes to the literature by filling three important gaps in the socialization literature. First, contrary to what previous meta- 
analysis suggests (e.g., Saks et al. 2007), we contend that the relative influence of context, content, and social tactics may vary across outcomes. Very few studies have empirically explored the relative influence of context, content, and social tactics using primary data. In this paper, we examine the relative importance of context, content, and social tactics using proximal outcome variables consistent with definitions of organizational socialization in terms of a learning process (e.g., Ashforth et al., 2007; Ostroff \& Kozlowski, 1992; Schein, 1968) in three key socialization domains: the organization, the work team, and the job (Haueter et al., 2003). Also, to stay true to Van Maanen and Schein's (1979) classic theory of organizational socialization, we include role innovation as an outcome variable directly related to socialization tactics.

Second, because context, content, and social tactics have been found to be correlated in past research (e.g., Ashforth, Saks, \& Lee, 1997; Jones, 1986), we contribute to the literature by using a more statistically appropriate method to evaluate their relative influence on role learning and innovation. Dominance analysis is a statistical technique that enables users to compare the relative importance, in terms of percentage of variance explained, of several predictor variables. It is appropriate when predictor variables are correlated, in which case the simple comparison of regression coefficient does not assess the relative strength of predictors (Johnson, 2000). Using a more appropriate statistical technique such as dominance analysis (Budescu, 1993; Budescu \& Azen, 2004) may change conclusions that can be drawn from the simple comparison of correlation or regression coefficients because these indices 'fail to consider both the effect the variable has by itself and in combination with the other variables' (Johnson, 2000: 1).

Finally, we chose to conduct the present study in France. Because globalization has '...changed the context in which organizational socialization now takes place.' 
(Feldman, 1997: 1), it is important to test general hypothesis in contexts other than those traditionally used in socialization studies. Bauer and Taylor (2001) recommend testing the relationship among variables in non-U.S. contexts in order to increase our understanding of socialization. Moreover, organizational socialization is a major concern in France (Lacaze \& Perrot, 2010), as it ranks number 5 in GDP in the world (World Bank, 2008), has a 8.1\% turnover rate in French firms and public administration (French Minister of Employment and Social Affairs, 2010) and the fact that industries report striving to attract, recruit, and retain the most qualified workers (French National Institute of Statistics and Economic Studies, 2007).

\section{Theoretical framework}

\section{Consequences of organizational socialization tactics}

Current research on organizational socialization is largely based on Van Maanen and Schein's original theoretical model (1979). Their classic model defined six types of tactics that organizations might employ based on what they refer to as 'the visible presence (or omnipresence) of a tactic across what appears to be a wide variety of organizations as well as the seeming importance and power of that tactic on persons who are subjected to it' (Van Maanen \& Schein, 1979: 232).

Collective (vs. individual) socialization consists of putting newcomers through a common set of experiences together, as opposed to a unique and individualized set of experiences. Formal (vs. informal) socialization refers to having newcomers geographically separated from other organizational members during a specific period of time. Sequential (vs. random) socialization involves establishing significant and identifiable steps towards to mastering target roles, as opposed to a random sequence. Fixed (vs. variable) socialization provides information regarding the timetable 
associated with the sequential tactic, as opposed to time uncertainty. Serial (vs. disjunctive) socialization is associated with the presence of role model(s), as opposed to not following the footsteps of predecessors. Investiture (vs. divestiture) confirms identity of the newcomer at the entry, as opposed to deny and strip away certain personal characteristics.

Beyond the definition of the six socialization tactics, the major contribution of Van Maanen and Schein's (1979) theory of organizational socialization is to frame specific propositions for each tactic, regarding its consequence in terms of role innovation or replication. Consistent with uncertainty reduction theory (Mignerey, Rubin, \& Gorden, 1995), Van Maanen and Schein (1979) assumed that adjustment to a new organizational role would be a source of anxiety and stress for newcomers, and proposed that individuals facing such situations will seek to reduce the uncertainty and stress levels. To the extent that organizations provide newcomers with information regarding role expectations, new recruits will therefore tend to conform to these expectations rather than to 'rock the boat.' Because collective, formal, sequential, and serial tactics reduce newcomer uncertainty and stress, they tend to be negatively associated with role innovation. Jones (1986) followed the same reasoning and hypothesized that institutionalized tactics facilitate role adjustment, and are negatively related to role innovation.

However, the theoretical reasoning is different regarding fixed (vs. variable) and investiture (vs. divestiture) tactics. On the one hand, Van Maanen and Schein (1979) proposed that variable and divestiture tactics create more anxiety than respectively fixed and investiture tactics. Therefore, individuals will be in greater need to conform to organizational expectations, which in turn will contribute to greater role replication and lower innovation. On the other hand, Jones (1986) argued that socialization tactics 
do not create stress, but offer different ways to reduce it. In other words, fixed (vs. variable) and investiture (vs. divestiture) tactics represent more explicit cues and guidelines as far as organizational expectations. Because newcomers will tend to conform to expectations, fixed (vs. variable) and investiture (vs. divestiture) tactics will be negatively related to role innovation. Subsequent empirical studies clearly supported Jones' (1986) predictions (Bauer et al., 1998). The literature therefore suggests that there is a similar theoretical reasoning to explain the influence of each of the six socialization tactics on all outcomes. In other words, institutionalized tactics (vs. individualized) decrease uncertainty and stress, thus facilitating adjustment while decreasing role innovation.

Although there is a common dimension between the six socialization tactics, and a common logic to explain how each tactic relates to socialization outcomes, other factors may reinforce or limit the strength of the relationship.

\section{Differential effects of context, content, and social tactics}

As Ashforth et al. (1997) note, Jones' (1986) tactics scale can be used as a onedimensional model (e.g., Kim, Cable, \& Kim, 2005) or as separate subscales. Specifically, Jones' (1986) tactics items can be either used as six separate subscales, or regrouped in three larger subscales that distinguish between context (collective and formal vs. individual and informal), content (fixed and sequential vs. variable and random), and social (serial and investiture vs. disjunctive and divestiture) tactics.

Previous research analyzing the differential effect of socialization tactics has largely relied on a three-dimensional model (Cable \& Parsons, 2001; Grant \& Bush, 1996; Jones, 1986), suggesting that context, content, and social tactics may have differentiated effects on several outcome variables. Saks et al. (2007) used meta analysis to summarize all empirical studies relating socialization tactics to a large 
number of socialization outcomes, regrouping the six tactics scales into context, content, and social types of tactics. Saks et al. (2007) found that the social tactics were the strongest predictor of eight socialization outcomes, and that the context tactics were the weakest predictor of six of the organizational socialization outcomes studied. In a similar vein, Jones (1986) found that investiture (vs. divestiture) and serial (vs. disjunctive) tactics loaded highest on the first canonical function, followed by fixed (vs. variable) and sequential (vs. random) tactics, thus suggesting that social tactics have more influence on newcomer socialization. Similar conclusions were drawn with other specific outcomes such as organizational value congruence (Grant \& Bush, 1996), person-organization fit (Cable \& Parsons, 2001), and information systems employee's adjustment (King \& Sethi, 1998).

Although previous studies contributed to the literature by suggesting a dominant effect of social tactics, three essential limitations are noted. First, the number of studies available for the meta-analysis (Saks et al., 2007) was relatively small. As Saks et al. (2007: 442) explain, 'less confidence is warranted when not all studies contributed to a meta-analytic coefficient.' Second, previous studies considered distal outcomes of socialization, whereas a greater use of proximal outcomes is needed (e.g., Ashforth et al., 2007; Saks et al., 2007). Third, almost all previous studies were not specifically focused on differential predictions, while exploring consequences of socialization tactics. Therefore, more research is needed on differential predictions by using relevant proximal outcomes, and a specific methodological design. 


\section{Hypotheses}

\section{Identifying relevant socialization outcome variables}

A large number of socialization outcomes have been considered in the literature, including organizational commitment, job satisfaction, intentions to quit, and job involvement. Because these concepts are not uniquely related to socialization, scholars have called for a higher focus on proximal outcomes of socialization (e.g., Gruman, Saks, \& Zeig, 2006; Kammeyer-Mueller \& Wanberg, 2003; Saks et al., 2007). Their call is supported by recent studies in which mediating effects between socialization tactics and distal outcomes were found. Such mediating variables included newcomer learning, information acquisition, proactive behaviors, role conflict, role ambiguity, self-efficacy, social acceptance, superior relations, co-worker relations, personorganization fit, and person-group fit (e.g., Ashforth et al., 2007; Bauer et al., 2007; Gruman et al., 2006; Kammeyer-Mueller \& Wanberg, 2003; Saks et al., 2007).

However, not all of these mediating variables should be used as proximal outcomes. Because we focus on how socialization tactics influence the degree to which newcomers are socialized, we argue that a specific socialization scale should be used as proximal outcome. Such a scale should be based on learning items for two reasons. First, organizational socialization is primarily referred to as a learning process. Second, it is consistent with previous findings suggesting that newcomer learning is one of the variables that mediate the relationship between socialization tactics and distal outcomes.

Furthermore, we also considered role innovation (vs. replication) as an important proximal socialization outcome, and included it in our study for two reasons. First, it is the main outcome variable considered in Van Maanen and Schein's original theory of socialization tactics. In other words, role innovation can be related to 
socialization tactics, based on well-established theoretical grounds. Second, socialization tactics have opposite effects on adjustment and role innovation. In other words, to the extent that organizations seek to increase innovation, there is a trade-off between increasing adjustment on the one hand, and not decreasing innovation on the other hand. Therefore, role innovation is a specific outcome in the sense that it relates to socialization tactics the opposite way than other adjustment indicators. Following past theorizing and research, we referred to role innovation and role replication as the two bipolar ends of the same continuum (e.g., Jones, 1986; Van Maanen \& Schein, 1979).

\section{Differential predictions for role learning}

As explained before, previous research leads to two general conclusions regarding the consequences of socialization tactics. First, institutionalized tactics improve adjustment while lowering role innovation (e.g., Ashforth et al., 2007; Jones, 1986; Saks et al., 2007). Second, because socialization tactics share a common dimension (Jones, 1986) in terms of institutionalization vs. individualization, there is a common logic to explain their effects on adjustment indicators and role orientation, based on stress reduction theory. In this paper, we argue that the relative influence of context, content, and social tactics varies across outcome variables. The question here is to know which type of socialization tactics (context, content, or social) will have the greater impact on role learning, referred to as the degree to which newcomers know and understand their organization, their job, and their coworkers (Haueter et al., 2003).

While a lot of research has been dedicated to understanding the effects of socialization tactics, other researchers focused on newcomers' proactivity and found that information seeking (e.g., Bauer \& Green, 1998; Brown, Ganesan, \& Challagalla, 2001; Morrison, 1993) and other proactive behaviors (e.g., Ashford \& Black, 1996; 
Gruman et al., 2006; Wanberg \& Kammeyer-Mueller, 2000) were associated with increased socialization success.

The logic behind these findings is that newcomers' proactivity facilitates interactions with other insiders, thus providing them with greater access to socialization sources (Kammeyer-Mueller \& Wanberg, 2003), and facilitating adjustment (e.g., Slaughter \& Zickar, 2006). In other words, social exchange strongly contributes to socialization (e.g., Sluss \& Thompson, 2009).

Moreover, we argue that such social interactions are facilitated not only by newcomers' proactive behaviors, but also by social tactics from the organization. Specifically, serial (vs. disjunctive) tactics provide newcomers with a role model, thus enabling them to better learn their new organizational role (Filstad, 2004) through observations, imitations, and questions. Also, investiture (vs. divestiture) tactics confirm the identity of the newcomer, thus increasing self-confidence in terms of impression management (e.g., Morrison \& Bies, 1991), which in turn encourages social interactions with insiders. Therefore, investiture tactics facilitate learning.

Because social tactics are related to increased social interactions with insiders, we predict that social tactics will be a stronger predictor of role learning than context and content tactics. In the following hypotheses, we use the concept of dominating variable (e.g., Budescu, 1993; Budescu \& Azen, 2004). When breaking down the total effect of the three predictors, the dominating predictor is referred to as the one that accounts for the greatest percentage of the total effect.

Hypothesis 1a. The social tactics will dominate the context and content tactics to more potently predict newcomer learning in the organizational domain.

Hypothesis $1 \mathrm{~b}$. The social tactics will dominate the context and content tactics to more potently predict newcomer learning in the work team domain. 
Hypothesis 1 c. The social tactics will dominate context and content tactics to more potently predict newcomer learning in the job domain.

\section{Differential predictions for role innovation}

As Bauer et al. (2007) note, the socialization process can be thought of as an uncertainty reduction process (e.g., Berger, 1979). Uncertainty reduction theory proposes that individuals in new situations are motivated and prefer situations that allow them to have greater prediction in terms of their interactions with others and their work (Berger \& Calabrese, 1975). As for learning, the common logic for all tactics is that institutionalized tactics offer ways to reduce uncertainty by conforming to organizational expectations, thus decreasing role innovation (e.g., Jones, 1986). Because role replication and role innovation are the two bipolar ends of the same continuum (e.g., Jones, 1986; Van Maanen \& Schein, 1979), one could also say that institutionalized tactics increase role replication.

Beyond this classic effect, we assert that the negative influence of content tactics on role innovation is reinforced because of their specific design. In other words, content tactics act like inhibitory contextual factors. Specifically, sequential (vs. random) tactics consist of identifying a set of specific steps towards target roles. Progression along this sequence of steps thus implies not only formalizing role expectations at each step, but also satisfying such expectations to progress along the sequence of steps. In other words, sequential tactics build a very clear road to follow and leave newcomers little room for exploring other paths through role innovation. Fixed (vs. variable) tactics consist of associating progression along the steps toward target roles with a timetable. This obviously reinforces the negative effects of sequential (vs. random) tactics on role innovation. 
Therefore, there are specific reasons that content tactics reinforce the relationship between socialization tactics and role replication, beyond their common effect explained by uncertainty reduction theory. Because the objective of content tactics is to guide newcomers' footsteps along a specific road towards target roles, we predict that content tactics will be a stronger predictor of role replication than context or social tactics.

Hypothesis 2. The content tactics will dominate context and social tactics to more potently predict role replication (as opposed to role innovation).

\section{Method}

\section{Sample and Procedure}

A questionnaire was sent to all masters degree alumni $(1,354)$ of a large public French university for that year's graduating class via the traditional mail system during the early months of their post-graduate employment, thus in real working life in organizational settings. A total of 201 questionnaires were filled and returned, while 56 were returned as unable to deliver due to a wrong address, resulting in a response rate of $15.6 \%$. Six questionnaires were excluded because of missing data, leaving 195 questionnaires available for analysis.

The response rate was lower than the average of $52.7 \%$ observed by Baruch and Holtom (2008) for studies published between 2000 and 2005 in US-based journals, using data collected from individuals. We follow the authors' recommendations in reporting response rates, and explain our lower response rate by the following reasons. First, as Baruch and Holtom (2008) found, response rates are higher in US-based journals than non US-based journals, which can be partly explained by differences in the population being studied. Second, with the exception of an accompanying letter 
from the President encouraging former students to respond, there was no possible incentive and responses were truly voluntary. To ensure respondents did not differ significantly from the total population, we asked the university their statistics about the same graduates we sent questionnaires to. We obtained such statistics regarding age and gender, that were respectively 26 years $(\mathrm{SD}=6)$ with $49 \%$ being women. In our sample, the average age of respondents was $25.8(S D=5.4)$ with $56 \%$ of the sample being women. In other words, our sample is comparable with the global population regarding age, although females tended to respond more frequently than male respondents. As explained in the method section, age and gender were included as control variables in regression analysis.

In terms of the remaining sample characteristics, five employees had organizational tenure of over two years. Excluding these five outliers from all future analyses, the remaining sample had an average organizational tenure of 7.40 months $(S D=4.22)$ which qualifies the remaining sample as newcomers with less than one year with their new organization (Bauer et al., 1998). The respondents worked in relatively large organizations with $24 \%$ in organizations with more than 10,000 employees, $25 \%$ in organizations with between 1,001 and 10,000 employees, $22 \%$ in organizations with between 201 and 1,000 employees, 13\% in organizations with between 51 and 200 employees, and only $16 \%$ working in organizations with no more than 50 employees. Respondents reported working in different economic sectors including banking, finance, and insurance (30.9\%), industry (16.2\%), auditing and consulting (15.7\%), communication and media (7.3\%), computer, software and information systems $(6.8 \%)$, and real estate $(5.8 \%)$. The remaining respondents worked in business sectors such as retailing, telecom, tourism, public sector and others which comprised less than $5 \%$ of our sample each. 
Measures

The scales were translated from English to French using a back translation procedure recommended by Brislin (1970). All of the variables in this study were assessed on a five-point Likert scale ranging from $1=$ strongly disagree to $5=$ strongly agree except where noted in the scale descriptions.

Socialization tactics. We used Jones' (1986) items, which are by far the most frequently used items in the socialization tactics literature. However, researchers have routinely removed certain items because of their poor loadings and used an either shorter (e.g., Black \& Ashford, 1995; Cable \& Parsons, 2001; Kim et al., 2005; King \& Sethi, 1998; Riordan, Weatherly, Vandenberg, \& Self, 2001) or modified (e.g., Ashforth \& Saks, 1996) version of Jones' (1986) scale. To ensure a better comparability of results, we followed Cable and Parsons (2001) who included only the two highest-loading items from each of the six tactics, based on Jones' (1986) empirical results. From the 12-items scale, three factors were extracted from a principal component analysis, corresponding to the context, content, and social facets of socialization tactics. Sample items from the context, content, and social aspects include, respectively, 'I have been through a set of training experiences that are specifically designed to give newcomers a thorough knowledge of job related skills,' 'The steps in the career ladder are clearly specified in this organization,' and 'I feel that experienced organizational members have held me at a distance until I conform to their expectations' (R). Item 1 from the collective versus individual scale was reworded: specifically, 'In the last 6 months...' was replaced by 'When joining the organization...' because some respondents may have had a tenure longer than six months. In this three-factor structure, all items loaded on the expected dimension: context, content, and social factors. However, three items (one on each dimension) had 
either a loading less than 0.5 , or two loadings greater than 0.3 on two axis. We therefore decided to drop these items for further analysis.

Learning variables. Out of the three main socialization scales (e.g., Chao, O'Leary-Kelly, Wolf, Klein, \& Gardner, 1994; Haueter et al., 2003; Taormina, 2004), we chose Haueter et al.'s (2003) because it entirely focuses on a learning approach to adjustment during socialization. We used all three subscales: organizational (12 items), work-team (12 items), and job (11 items) domains of socialization. Each subscale include respectively 'I understand this organization's objectives and goals,' 'I know my work group's objectives,' and 'I understand which job tasks and responsibilities have priority.'

Role innovation. To be consistent with past literature, we used Jones' (1986) role innovation / replication scale and dropped the problematic item which has been deemed as too ambiguous in past research (Allen \& Meyer, 1990). The four items used were 'I have made an attempt to redefine my role and change what I am required to do,' 'I have changed the mission or purpose of my role,' 'The procedures for performing my job are generally appropriate in my view' (R), 'I have tried to change the procedures for doing my job to institute new work goals.'

Control variables. As Becker (2005) notes, control variables are important to consider. In order to build upon and extend previous studies, we identified several potentially relevant control variables in the literature. Because past research underlined the importance of newcomer proactivity in the interactive socialization process (e.g., Ashford \& Black, 1996; Ashforth et al., 2007; Gruman et al., 2006), we included proactive personality as a potential control variable. The 6-items version of the proactive personality scale from Bateman and Crant (1993) was used because it has been found to be most consistent across cultures (Claes, Beheydt, \& Lemmens, 2005). 
Following Kammeyer-Mueller and Wanberg (2003), we also included four demographic control variables in the socialization literature age, gender, organization size, and organizational tenure. While research has not concluded that gender is a major determinant of socialization, it is always possible that gender may matter, therefore, we gathered this information and men were coded as 0 and women were coded as 1 . Organization size has the potential to influence the formalization of the socialization process and which tactics are employed. Therefore, this was measured with a scale ranging from low to high with 5 pre-defined ranges ( 1 for 0 to 50 employees, 2 for 51 to 200 employees, 3 for 201 to 1000 employees, 4 for 1,001 to 10,000 employees, and 5 for more than 10,000 employees). Finally, because time is such an important part of the socialization process, organizational tenure was measured in months since entry to allow for its use as a control variable.

\section{Results}

Principal component analysis, descriptive statistics, correlations, and reliability coefficients

To ensure items from the socialization tactics scale loaded on the expected dimensions, we conducted a principal component analysis. Results display a clear, three-dimensional structure, as reported in Table 1.

Descriptive statistics, correlations, and reliability estimates are reported in Table 2. Mean scores underlie that employees experienced more institutionalized tactics, especially for social tactics. Standard deviations were relatively high, indicating a wide variety of socializing experiences perceived in our sample, across organizations. The mean scores for socialization tactics, using a five-point Likert scale, suggest that the respondents experienced a wide variety of socialization tactics from their organizations 
with a mean of $2.77(S D=1.05)$ for context tactics, $2.75(S D=0.96)$ for content tactics, and $3.72(S D=0.87)$ for social tactics. More generally, respondents were similar in terms of level of study, but differed significantly in terms of major, job type, business sector, and company size.

The pattern of correlations suggests that all types of socialization tactics are positively correlated, because they share a common dimension in terms of institutionalization vs. individualization. Correlation between context and content seems to be higher than others. All types of tactics are positively related to the three learning variables and negatively related to role innovation, which is consistent with previous research suggesting that institutionalization of tactics facilitates newcomers' adjustment, while limiting role innovation. Finally, learning variables and role innovation are not significantly correlated, suggesting that these indicators capture different aspects of adjustment.

\section{Analytic Strategy}

Estimating the relative strength of predictor variables is straightforward when all independent variables are uncorrelated, with simple comparisons of correlation or regression coefficients. However, such comparisons of coefficients are uninterpretable when predictors are correlated (Johnson, 2000). Because we found significant correlations between the three types of tactics, as suggested by previous research, a more adapted analytic strategy was needed that accounts for both the effect of each predictor variable separately, and when combined with the other predictor variables (Johnson, 2000).

Dominance analysis (Budescu, 1993; Budescu \& Azen, 2004) and estimation of the relative weight of predictor variables in multiple regressions (Johnson, 2000) are two possible approaches to account for correlations between predictor variables, while 
estimating their relative influence. As Lebreton and Tonidandel (2008) noticed, such techniques have been used increasingly in the last several years. Johnson (2000) argued that relative weight should be used when the number of predictor variables is equal or greater than 5, because computational requirements of dominance analysis increase exponentially. In this study, we chose dominance analysis (Budescu, 1993; Budescu \& Azen, 2004) because only three predictor variables (context, content, and social tactics) were included.

\section{Dominance analysis}

As stated before, dominance analysis is appropriate to assess the relative importance of several correlated predictors. A predictor is referred to as dominant when it explains more variance in the dependent variables when compared to other predictors. As explained by Budescu (1993), dominance analysis requires two steps. The first step is referred to as qualitative (Budescu, 1993), and tests whether one variable dominates another (Table 3). Considering three predictor variables $\left(\mathrm{X}_{\mathrm{i}}, \mathrm{X}_{\mathrm{j}}, \mathrm{X}_{\mathrm{k}}\right), \mathrm{X}_{\mathrm{i}}$ dominates $\mathrm{X}_{\mathrm{j}}$ if $\mathrm{R}^{2}\left(\mathrm{X}_{\mathrm{i}}\right)>\mathrm{R}^{2}\left(\mathrm{X}_{\mathrm{j}}\right)$ and $\left[\mathrm{R}^{2}\left(\mathrm{X}_{\mathrm{i}}, \mathrm{X}_{\mathrm{k}}\right)-\mathrm{R}^{2}\left(\mathrm{X}_{\mathrm{k}}\right)\right]>\left[\mathrm{R}^{2}\left(\mathrm{X}_{\mathrm{j}}, \mathrm{X}_{\mathrm{k}}\right)-\mathrm{R}^{2}\left(\mathrm{X}_{\mathrm{k}}\right)\right]$.

Social tactics (X3) were hypothesized to be the strongest predictor of learning variables. In other words, we predicted that social tactics dominated both content (X2) and context (X1) tactics. As shown in table 3 for the organizational domain, X3 dominates X2 $(.076>.036$ and $.062>.015)$, and X2 dominates X1 $(.036>.026$ and $.014>.012$ ). Because dominance is transitive (Budescu, 1993), social tactics are the strongest predictor of organizational learning, and H1a is supported through qualitative dominance analysis.

As for work team learning, X3 dominates X2 (.121>.059 and .102>.03), and X2 dominates X1 $(.059>.034$ and $.024>.015)$. Therefore, social tactics are the 
strongest predictor of work team learning and $\mathrm{H} 1 \mathrm{~b}$ is supported through qualitative dominance analysis.

Similarly, as for job learning, X3 dominates X2 $(.098>.058$ and $.083>.035)$, and X2 dominates X1 $(.058>.025$ and $.026>.01)$. Therefore, social tactics are the strongest predictor of job learning and H1c is supported through qualitative dominance analysis.

Beyond qualitative analysis, Budescu (1993) recommends to quantify the relative effect of each predictor variable, based on the average of direct, partial, and total effects. With three predictor variables $\left(\mathrm{X}_{\mathrm{i}}, \mathrm{X}_{\mathrm{j}}, \mathrm{X}_{\mathrm{k}}\right)$, the percentage of total effect explained by $\mathrm{X}_{\mathrm{i}}$ is $\mathrm{M}\left(\mathrm{C}_{\mathrm{Xi}}\right)$, which is the average of $\mathrm{C}_{\mathrm{Xi}}{ }^{(0)}=\mathrm{R}^{2}\left(\mathrm{X}_{\mathrm{i}}\right), \mathrm{C}_{\mathrm{Xi}}{ }^{(1)}=\left\{\left[\left(\mathrm{R}^{2}\left(\mathrm{X}_{\mathrm{i}}, \mathrm{X}_{\mathrm{j}}\right)\right.\right.\right.$ $\left.\left.-\mathrm{R}^{2}\left(\mathrm{X}_{\mathrm{j}}\right)\right]+\left[\mathrm{R}^{2}\left(\mathrm{X}_{\mathrm{i}}, \mathrm{X}_{\mathrm{k}}\right)-\mathrm{R}^{2}\left(\mathrm{X}_{\mathrm{k}}\right)\right]\right\} / 2$, and $\mathrm{C}_{\mathrm{Xi}}^{(2)}=\mathrm{R}^{2}\left(\mathrm{X}_{\mathrm{i}}, \mathrm{X}_{\mathrm{j}}, \mathrm{X}_{\mathrm{k}}\right)-\mathrm{R}^{2}\left(\mathrm{X}_{\mathrm{j}}, \mathrm{X}_{\mathrm{k}}\right)$. Quantitative analysis provides additional perspective on results, because it quantifies the relative effect of each predictor variable in terms of percentage of total effect.

Hypothesis H1a, H1b and H1c were supported through quantitative analysis as social tactics accounted for the highest percentage (ranging from $63 \%$ to $67 \%$ ) of the total effect of socialization tactics on learning variables, as reported in Table 4.

For role replication, we hypothesized that content tactics was the strongest predictor, because such tactics are especially designed to build roads and steps towards target roles, thus signaling newcomers that adjustment is easier through conformity than innovation. Through qualitative dominance analysis (Table 5), it appears that X2 dominates X1 $(.072>.061$ and $.052>.047)$ and X1 dominates X3 $(.061>.031$ and $.016>.011$ ). Quantitative analysis (Table 5) emphasizes that content tactics account for almost $45 \%$ of the total effects of all socialization tactics on role replication. Therefore, content tactics is the strongest predictor of role replication and hypothesis 2 is supported. 
Supplementary analyses

Because dominance analysis does not take into account the potential effect of control variables, we replicated the results using regression analysis with control variables. To examine their potential influence, we first examined the correlation matrix and selected the control variables that significantly $(p<.01)$ correlated to the variables of interest for this study. We found that proactive personality was positively correlated to learning (about the organization, the work group, and the job) and role innovation, and organizational size was correlated to organizational learning. However, age, gender, and organizational tenure were not correlated to any of the variables of interest in the present study. We therefore included proactive personality and organizational size as control variables in each regression analysis. Comparisons of beta coefficients between context, content, and social tactics showed results consistent with dominance analysis.

\section{Discussion}

The present study argued that social tactics were the best predictor for learning outcomes, whereas content tactics were the best predictor for role innovation. This prediction was supported. Specifically, we found that social tactics were the strongest predictor of all learning variables $(\mathrm{H} 1 \mathrm{a}, \mathrm{H} 1 \mathrm{~b}, \mathrm{H} 1 \mathrm{c})$, whereas content tactics were the strongest predictors of role replication $(\mathrm{H} 2)$.

\section{Theoretical implications}

From a theoretical perspective, these results are important for three main reasons. First, our study found that the relative influence of context, content, and social tactics varies across outcomes. In other words, although social tactics were the best 
predictor for most outcomes, content tactics better predicted role innovation. Second, we suggest that the impact of socialization tactics is not only based on a common factor in terms of institutionalization vs. individualization, but also lies on a more complex pattern of relationships between different types of socialization tactics and outcomes. Third, we propose new insights regarding how social tactics influence role innovation. We argue in particular that investiture tactics have conflicting effects on role innovation. On the one hand, uncertainty reduction theory is used to explain why investiture tactics are negatively related to role innovation. This uncertainty reduction effect is dominant, as found in previous empirical studies (e.g., Jones, 1986). On the other hand, because investiture tactics confirm newcomers' identity, they also increase newcomers' self-confidence, which in turn facilitates role innovation. Therefore, it is likely that conflicting effects of investiture tactics on role innovation lower their relative importance, as well as that of social tactics, as a predictor variable for role innovation.

\section{Practical Implications}

From a practical perspective, several implications may be evolved from this study. To the extent that organizations want to foster learning, social tactics are the most effective. This is true for the three learning domains: the organization, the work team, and the job. Conversely, the issue of processing people on a collective vs. individual basis, or in a formal vs. informal way, is of less importance in that respect. Although it can be assumed that companies generally have interest to foster learning, different objectives can be pursued regarding role innovation. For companies willing to develop role replication (vs. role innovation), a mix of social and content tactics will be more effective: social tactics will foster learning most effectively, and content tactics will contribute to role replication (vs. role innovation). However, there are no types of 
tactics that simultaneously foster learning and role innovation. For companies willing to develop role innovation, random and variable tactics seem most appropriate. However, to the extent that individualized tactics are defined by what they are not rather than by what they are (Ashforth \& Saks, 1996; Ashforth et al., 1997; Bravo, Peiro, Rodriguez, Whitely, 2003), one should rather conclude that content tactics (sequential and fixed vs. random and variable) must not be used to preserve role innovation. In other words, companies must find a trade-off and use social tactics to have a strong effect on learning and a more limited, yet undesired, impact on role innovation, while avoiding the use of content tactics.

\section{Potential Limitations and Future Research Directions}

We identified three potential limitations of the present study. First, because data were collected using a cross-sectional design, causality cannot be verified. However, our study was not specifically aimed at testing causal relationships per se, but focused instead on exploring the relative influence of predictors that have already been established as such in the literature. Another potential limitation deals with the nature of outcome variables included in the research model. This one focused on proximal outcomes in arguing that learning variables were relevant because they measured the impact of socialization tactics on the degree to which newcomers are socialized, as opposed to general and distal outcomes. Similarly, role innovation is an essential proximal outcome to consider because it is fundamentally grounded into Van Maanen and Schein (1979)'s classic theory of socialization. However, to further establish the importance of differential effects, a larger variety of outcomes should be included in future studies, as well as different environments (Anglo-Saxon and others). We hope to stimulate research in that direction, in order to more fully understand the way context, content, and social tactics differentially predict specific outcomes, beyond their 
common effect associated with the degree of institutionalization (vs. individualization). Finally, limitations regarding the characteristics of data should be mentioned. The use of self-report data may introduce a consistency bias, especially when analyzing relationships between several attitudinal variables. However, socialization tactics items referred to perceived managerial practices but not attitudinal variables, thus minimizing common method variance. The low response rate could also be mentioned as a potential limitation, but our sample was comparable with the global population on several characteristics, suggesting that self-selection bias was not a serious concern.

\section{Conclusion}

In conclusion, the present study extended the literature on socialization tactics by examining a wider array of highly relevant proximal outcomes, utilizing dominance analysis, and making and supporting differential predictions. Specifically, we predicted and found that the relative influence of context, content, and social tactics varies across outcomes. Organizational socialization is a critical process for newcomers and organizations alike. By understanding the different levers of socialization that organizations have available for them, they can more effectively engage in strategic human resource management (SHRM) and new employee onboarding. 


\section{References}

ALLEN, D.G. (2006) "Do organizational socialization tactics influence newcomer embeddedness and turnover?", Journal of Management, Vol. 32, pp. 237-256.

ALLEN, N.J., \& MEYER, J.P. (1990) “Organizational socialization tactics: A longitudinal analysis of links to newcomers' commitment and role orientation", Academy of Management Journal, Vol. 33, pp. 847-858.

ASHFORD, S.J., \& BLACK, J.S. (1996) "Proactivity during organizational entry: The role of desire for control”, Journal of Applied Psychology, Vol. 81, pp. 199-214. ASHFORTH, B.E., \& SAKS, A.M. (1996) "Socialization tactics: Longitudinal effects on newcomer adjustment”, Academy of Management Journal, Vol. 39, pp. 149-178. ASHFORTH, B.E., SAKS, A.M., \& LEE, R.T. (1997) “On the dimensionality of Jones' (1986) measures of organizational socialization tactics", International Journal of Selection and Assessment, Vol. 5, pp. 200-214.

ASHFORTH, B.E., SLUSS, D.M., \& SAKS, A.M. (2007) “Socialization tactics, proactive behavior, and newcomer learning: Integrating socialization models", Journal of Vocational Behavior, Vol. 70, pp. 447-462.

BARUCH, Y., \& HOLTOM, B.C. (2008) "Survey response rate levels and trends in organizational research" Human Relations, Vol. 61, pp. 1139-1160.

BATEMAN, T.S., \& CRANT, J.M. (1993) “The proactive component of organizational behavior: A measure and correlates", Journal of Organizational Behavior, Vol. 14, pp. $103-118$.

BAUER, T.N., BODNER, T., ERDOGAN, B., TRUXILLO, D.M., \& TUCKER, J.S. (2007) "Newcomer adjustment during organizational socialization: A meta-analytic 
review of antecedents, outcomes, and methods", Journal of Applied Psychology, Vol. 92, pp. 707-721.

BAUER, T.N., \& GREEN, S.G. (1998) “Testing the combined effects of newcomer information seeking and manager behavior on socialization", Journal of Applied Psychology, Vol. 83, pp. 72-83.

BAUER, T.N., MORRISON, E.W., \& CALLISTER, R.R. (1998) “Organizational socialization: A review and directions for future research", Research in Personnel and Human Resources Management, Vol. 16, pp. 149-214.

BAUER, T.N., \& TAYLOR, M.S. (2001) A globalized conceptualization of organizational socialization. In N. ANDERSON, D. S. ONES, H. K. SINANGIL, \& C. VISWESVARAN (Eds.), International Handbook of Industrial, Work, and Organizational Psychology, (Volume 1, pp. 409-423). New York: Sage Press.

BECKER, T. E. (2005) "Potential problems in the statistical control of variables in organizational research: A qualitative analysis with recommendations”, Organizational Research Methods, Vol. 8, pp. 274-289.

BERGER, C.R. (1979) Beyond initial interaction: Uncertainty, understanding, and the development of interpersonal relationships, In H. GILES \& R. N. St. CLAIR (Eds.), Language and social psychology (pp. 122-144). Baltimore: University Park Press.

BERGER, C.R., \& CALABRESE, R.J. (1975) « Some explorations in initial interaction and beyond: Toward a developmental theory of interpersonal communication », Human Communication Research, Vol. 1, pp. 99-112.

BLACK, J.S., \& ASHFORD, S.J. (1995) "Fitting in or making jobs fit: Factors affecting mode of adjustment for new hires”, Human Relations, Vol. 48, pp. 421437. 
BRANHAM, L. (2000) Keeping the people who keep you in business, New York: Amacom, American Management Association.

BRAVO, M.J., PEIRO, J.M., RODRIGUEZ, I., \& WHITELY, W.T. (2003) “Social antecedents of the role stress and career enhancing strategies of newcomers to organizations: A longitudinal study", Work \& Stress, Vol. 17, pp. 195-217.

BRISLIN, R. W. (1970) “Back-translation for cross-cultural research”, Journal of Cross Cultural Psychology, Vol. 1, pp. 185-216.

BROWN S.P., GANESAN S., \& CHALLAGALLA G. (2001) "Self-efficacy as a moderator of information seeking effectiveness", Journal of Applied Psychology, Vol. 86, pp. 1043-1051.

BUDESCU, D.V. (1993) "Dominance analysis: A new approach to the problem of relative importance of predictors in multiple regression", Psychological Bulletin, Vol. 114, pp. 542-551

BUDESCU, D.V., AZEN, R. (2004) "Beyond global measures of relative importance: Some insights from dominance analysis”, Organizational Research Methods, Vol. 7, $\mathrm{N}^{\circ} 3$, pp. 341-350.

Cable D.M., \& PARSONS, C.K. (2001) "Socialization tactics and person-organization fit”, Personnel Psychology, Vol. 54, pp. 1-23.

CHAO, G.T., O'LEARY-KELLY, A.M., WOLF, S., KLEIN, H.J., \& GARDNER, P.D. (1994) “Organizational socialization: Its content and consequences”, Journal of Applied Psychology, Vol. 79, pp. 730-743.

CLAES, R., BEHEYDT, C., \& LEMMENS, B. (2005) « Unidimensionality of abbreviated proactive personality scales across cultures", Applied Psychology: An International Review, Vol. 54, pp. 476-489. 
FELDMAN, D.C. (1981) “The multiple socialization of organization members”, Academy of Management Review, Vol. 6, pp. 309-318.

FELDMAN, D.C. (1997) "Socialization in an international context", International Journal of Selection and Assessment, Vol. 5, pp. 1-8.

FILSTAD, C. (2004) "How newcomers use role models in organizational socialization", Journal of Workplace Learning: Employee Counseling Today, Vol. 16, pp. 396-409.

French Minister of Employement and Social Affairs (2010). Eléments sur les mouvements de main-d'oeuvre dans les établissements d'au moins dix salaries. French Minister of Employement and Social Affairs, DARES, January 2010. French National Institute of Statistics and Economic Studies (2007). http://www.insee.fr/sessi//4pages/230/principal.htm.

GRANT, E.S., \& BUSH, A.J. (1996) “Salesforce socialization tactics: Building organizational value congruence”, Journal of Personal Selling \& Sales Management, Vol. 16, pp. 17-32.

GRIFFIN, A.E.C., COLELLA, A., \& GOPARAJU, S. (2000) "Newcomer and organizational socialization tactics : An interactionist perspective", Human Resource Management Review, Vol. 10, pp. 453-72.

GRUMAN, J.A., SAKS, A.M., \& ZEIG, D.I. (2006) “Organizational socialization tactics and newcomer proactive behaviors: An integrative study", Journal of Vocational Behavior, Vol. 69, pp. 90-104.

HAUETER, J.A., MACAN, T.H., \& WINTER, J. (2003) "Measurement of newcomer socialization: Construct validation of a multidimensional scale", Journal of Vocational Behavior, Vol. 63, pp. 20-39. 
JOHNSON, J.W. (2000) “A heuristic method for estimating the relative weight of predictor variables in multiple regression", Multivariate Behavioral Research, Vol. 35, pp. 1-19.

JONES, G.R. (1986) “Socialization tactics, self efficacy, and newcomers' adjustments to organizations", Academy of Management Journal, Vol. 29, pp. 262-279.

KAMMEYER-MUELLER, J.D., \& WANBERG, C.R. (2003) "Unwrapping the organizational entry process: Disentangling multiple antecedents and their pathways to adjustment”, Journal of Applied Psychology, Vol. 88, pp. 779-794.

KIM, T.Y., CABLE, D.M., \& KIM, S.P. (2005) “Socialization tactics, employee proactivity, and person-organization fit”, Journal of Applied Psychology, Vol. 90, pp. 232-241.

KING, R.C., \& SETHI, V. (1998) "The impact of socialization on the role adjustment of information systems professionals", Journal of Management Information Systems, Vol. 14, pp. 195-217.

LACAZE, D., \& PERROT, S. (2010) L'intégration des nouveaux collaborateurs, Paris: Dunod.

LEBRETON J.M., TONIDANDEL, S. (2008) "Multivariate relative importance: Extending relative weight analysis to multivariate criterion spaces", Journal of Applied Psychology, Vol. 93, n², pp. 329-345.

MIGNEREY, J.T., RUBIN, R.B., \& GORDEN, W.I. (1995) “Organizational entry: An investigation of newcomer communication behavior and uncertainty", Communication Research, Vol. 22, pp. 54-85.

MORRISON, E.W. (1993) "Newcomer information seeking: Exploring types, modes, sources, and outcomes", Academy of Management Journal, Vol. 36, pp. 557-589. 
MORRISON, E.W., \& BIES, R.J. (1991) “Impression management in the feedbackseeking process: A literature review and research agenda", Academy of Management Review, Vol. 16, pp. 522-541.

OSTROFF, C., \& KOZLOWSKI, S.W.J. (1992) “Organizational socialization as a learning process: The role of information acquisition”, Personnel Psychology, Vol. 45, pp. 849-874.

PERROT, S. (2009) "Les relations entre tactiques de socialisation et adéquations perçues”, Revue de Gestion des Ressources Humaines, Vol. 72, pp. 13-30.

RIORDAN, C.M., WEATHERLY, E.W., VANDENBERG, R.J., \& Self, R.M. (2001) "The effects of pre-entry experiences and socialization tactics on newcomer attitudes and turnover”, Journal of Managerial Issues, Vol. 13, pp. 159-176.

SAKS, A.M., UGGERSLEV K.L., \& FASSINA, N.E. (2007) "Socialization tactics and newcomer adjustment: A meta-analytic review and test of a model", Journal of Vocational Behavior, Vol. 70, pp. 413-46.

SCHEIN, E.H. (1968) “Organizational socialization and the profession of management”, Industrial Management Review, Vol. 9, pp. 1-16.

SLAUGHTER, J.E., \& ZICKAR, M. J. (2006) "A new look at the role of insiders in the newcomer socialization process", Group \& Organization Management, Vol. 31, pp. 264-290.

SLUSS, D.M., \& THOMPSON, B.S. (2009) “Socialization and social exchange: Leader-member exchange as mediator between tactics and attachment", Academy of Management Annual Meeting Proceedings,from the Annual Meeting, Chicago, IL. 
TAKEUCHI, N., \& TAKEUCHI, T. (2009) “A longitudinal investigation on the factors affecting newcomers' adjustment: Evidence from Japanese organizations”, International Journal of Human Resource Management, Vol. 20, pp. 928-952.

TAORMINA, R.J. (2004) “Convergent validation of two measures of organizational socialization”, International Journal of Human Resource Management, Vol. 15, pp. 76-94.

VAN MAANEN, J., \& SCHEIN, E.H. (1979) “Towards a theory of organizational socialization”, Research in Organizational Behavior, Vol. 1, pp. 209-264.

WESSON, M.J., \& GOGUS, C.I. (2005) "Shaking hands with a computer: An examination of two methods of organizational newcomer orientation", Journal of Applied Psychology, Vol. 90, pp. 1018-1026.

WHARTON, R., POTTER, P., \& PARRY, L.E. (2004) "Keeping the faculty: Issues of socialization, justice, and commitment to the workplace", Journal of Behavioral and Applied Management, Vol. 6, pp. 4-20.

World Bank (2008). Gross domestic product 2008. http://siteresources.worldbank.org/DATASTATISTICS/Resources/GDP.pdf 
Table 1

Principal component analysis of socialization tactics items.

\begin{tabular}{|l|c|c|c|}
\hline Items from Jones (1986) & Context & Social & Content \\
\hline Collective-individual 5 & $\mathbf{. 8 3}$ & .01 & .12 \\
\hline Collective-individual 1 & $\mathbf{. 8 2}$ & -.07 & -.12 \\
\hline Formal-informal 1 &. $\mathbf{7 1}$ & .13 & -.17 \\
\hline Serial-disjunctive 3 & .14 & $\mathbf{. 8 4}$ & -.01 \\
\hline Investiture-divestiture 5 & -.03 &. $\mathbf{7 9}$ & -.12 \\
\hline Investiture-divestiture 2 & -.06 & .75 & .09 \\
\hline Sequential-random 1 & -.12 & .04 & $\mathbf{- . 8 5}$ \\
\hline Sequential-random 5 & .08 & .06 & $\mathbf{- . 8 3}$ \\
\hline Fixed-variable 1 & .13 & -.07 & $\mathbf{- . 6 5}$ \\
\hline
\end{tabular}

Note. Extraction Method: Principal Component Analysis. Loadings $<0.3$ are not reported. Rotation method: Oblimin with Kaiser Normalization (converged in 6 iterations). 
Table 2

Means, Standard Deviations, Correlations, and Reliability Estimates

\begin{tabular}{|l|l|l|l|l|l|l|l|l|l|}
\hline Variable & $\mathrm{M}$ & $\mathrm{SD}$ & 1 & 2 & 3 & 4 & 5 & 6 & 7 \\
\hline $\begin{array}{l}\text { 1. Context } \\
\text { tactics }\end{array}$ & 2.77 & 1.05 & $(.75)$ & & & & & & \\
\hline $\begin{array}{l}\text { 2. Content } \\
\text { tactics }\end{array}$ & 2.75 & 0.96 & $0.52^{* *}$ & $(.72)$ & & & & & \\
\hline 3. Social tactics & 3.72 & 0.87 & $0.19^{*}$ & $0.28^{* *}$ & $(.73)$ & & & & \\
\hline $\begin{array}{l}\text { 4. Learning } \\
\text { (organizational } \\
\text { domain) }\end{array}$ & 4.09 & 0.47 & $0.16^{*}$ & $0.19^{*}$ & $0.28^{* *}$ & $(.86)$ & & & \\
\hline $\begin{array}{l}\text { 5. Learning } \\
\text { (work-team } \\
\text { domain) }\end{array}$ & 4.05 & 0.45 & $0.19^{*}$ & $0.24^{* *}$ & $0.35^{* *}$ & $0.58^{* *}$ & $(.87)$ & & \\
\hline $\begin{array}{l}\text { 6. Learning (job } \\
\text { domain) }\end{array}$ & 4.19 & 0.44 & $0.16^{*}$ & $0.24^{* *}$ & $0.31^{* *}$ & $0.52^{* *}$ & $0.66^{* *}$ & $(.85)$ & \\
\hline $\begin{array}{l}\text { 7. Role } \\
\text { replication }\end{array}$ & 2.69 & 0.88 & $0.25^{* *}$ & $0.27^{* *}$ & $0.18^{* *}$ & -0.13 & -0.02 & -0.04 & $(.80)$ \\
\hline
\end{tabular}

Notes. $N=181$. Alphas appear along the diagonal in parentheses.

$* p<0.05$

$* * p<0.01$. 
Table 3

Qualitative dominance analysis for learning variables

\begin{tabular}{|c|c|c|c|c|c|c|c|c|c|c|c|c|}
\hline & \multicolumn{4}{|c|}{ Organization learning } & \multicolumn{4}{|c|}{ Work team learning } & \multicolumn{4}{|c|}{ Job learning } \\
\hline & $\mathrm{R}^{2}$ & $\mathrm{X} 1$ & $\mathrm{X} 2$ & $\mathrm{X} 3$ & $\mathrm{R}^{2}$ & $\mathrm{X} 1$ & $\mathrm{X} 2$ & X3 & $\mathrm{R}^{2}$ & $\mathrm{X} 1$ & $\mathrm{X} 2$ & X3 \\
\hline & 0 & .026 & .036 & .076 & 0 & .034 & .059 & .121 & 0 & .025 & .058 & .098 \\
\hline $\mathrm{X} 1$ & .026 & & .015 & .062 & .034 & & .03 & .102 & .025 & & .035 & 083 \\
\hline $\mathrm{X} 2$ & .036 & .005 & & .054 & .059 & .005 & & .086 & .058 & .002 & & .066 \\
\hline $\mathrm{X} 3$ & .076 & .012 & .014 & & .121 & .015 & .024 & & .098 & .01 & .026 & \\
\hline $\mathrm{X} 1, \mathrm{X} 2$ & .041. & & & .052 & .064 & & & .083. & .060 & & & .065 \\
\hline $\mathrm{X} 1, \mathrm{X} 3$ & .088 & & .005 & & .136 & & .011 & & .108 & & .017 & \\
\hline $\mathrm{X} 2, \mathrm{X} 3$ & .090 & .003 & & & 145 & .002 & & & .124 & .001 & & \\
\hline Total effect: & .093 & & & & .147 & & & & .125 & & & \\
\hline
\end{tabular}

Notes. $\mathrm{X} 1=$ context, $\mathrm{X} 2=$ content, and $\mathrm{X} 3=$ social. 
Table 4

Quantitative dominance analysis for learning variables

\begin{tabular}{|l|l|l|l|l|l|l|l|l|l|}
\hline & \multicolumn{3}{|l|}{ Organizational learning } & \multicolumn{3}{l}{ Work team learning } & \multicolumn{3}{l|}{ Work team learning } \\
\hline $\mathrm{k}$ & $\mathrm{X} 1$ & $\mathrm{X} 2$ & $\mathrm{X} 3$ & $\mathrm{X} 1$ & $\mathrm{X} 2$ & $\mathrm{X} 3$ & $\mathrm{X} 1$ & $\mathrm{X} 2$ & $\mathrm{X} 3$ \\
\hline 0 & .026 & .036 & .076 & .034 & .059 & .121 & .025 & .058 & .098 \\
\hline 1 & .0085 & .0145 & .058 & .01 & .027 & .094 & .006 & .0305 & .0745 \\
\hline $\mathrm{M}(=$ & .003 & .005 & .052 & .002 & .011 & .083 & .001 & .017 & .065 \\
\hline $\mathrm{C}$ & .1344 & .1989 & .6666 & .1043 & .2199 & .6757 & .0853 & .2813 & .6333 \\
\hline$\%$ & 13.44 & 19.89 & $\mathbf{6 6 . 6 6}$ & 10.43 & 21.99 & $\mathbf{6 7 . 5 7}$ & 8.53 & 28.13 & $\mathbf{6 3 . 3 3}$ \\
\hline
\end{tabular}

Notes. $\mathrm{X} 1=$ context, $\mathrm{X} 2=$ content, $\mathrm{X} 3=$ social. 
Table 5

Qualitative and quantitative analysis for role replication

\begin{tabular}{|c|c|c|c|c|c|c|c|c|}
\hline \multicolumn{5}{|c|}{ Qualitative analysis } & \multicolumn{4}{|c|}{ Quantitative analysis } \\
\hline Variables & $\mathrm{R}^{2}$ & $\mathrm{X} 1$ & $\mathrm{X} 2$ & $\mathrm{X} 3$ & $\mathrm{k}$ & $\mathrm{X} 1$ & $\mathrm{X} 2$ & X3 \\
\hline & 0 & .061 & .072 & .031 & 0 & .061 & .072 & 031 \\
\hline $\mathrm{X} 1$ & .061 & & .027 & .017 & 1 & .0315 & .0395 & 014 \\
\hline $\mathrm{X} 2$ & .072 & .016 & & .011 & 2 & .014 & .019 & .009 \\
\hline $\mathrm{X} 3$ & .031 & .047 & .052 & & $\mathrm{M}\left(=\mathrm{C}_{\mathrm{XI}}\right)$ & .3659 & .4484 & .1855 \\
\hline $\mathrm{X} 1, \mathrm{X} 2$ & .088 & & & .009 & $\%$ & 36.59 & 44.84 & 18.55 \\
\hline $\mathrm{X} 1, \mathrm{X} 3$ & .078 & & .019 & & & & & \\
\hline $\mathrm{X} 2, \mathrm{X} 3$ & .083 & .014 & & & & & & \\
\hline Total effect: & .097 & & & & & & & \\
\hline
\end{tabular}

Notes. $\mathrm{X} 1=$ context, $\mathrm{X} 2=$ content, and $\mathrm{X} 3=$ social. 